
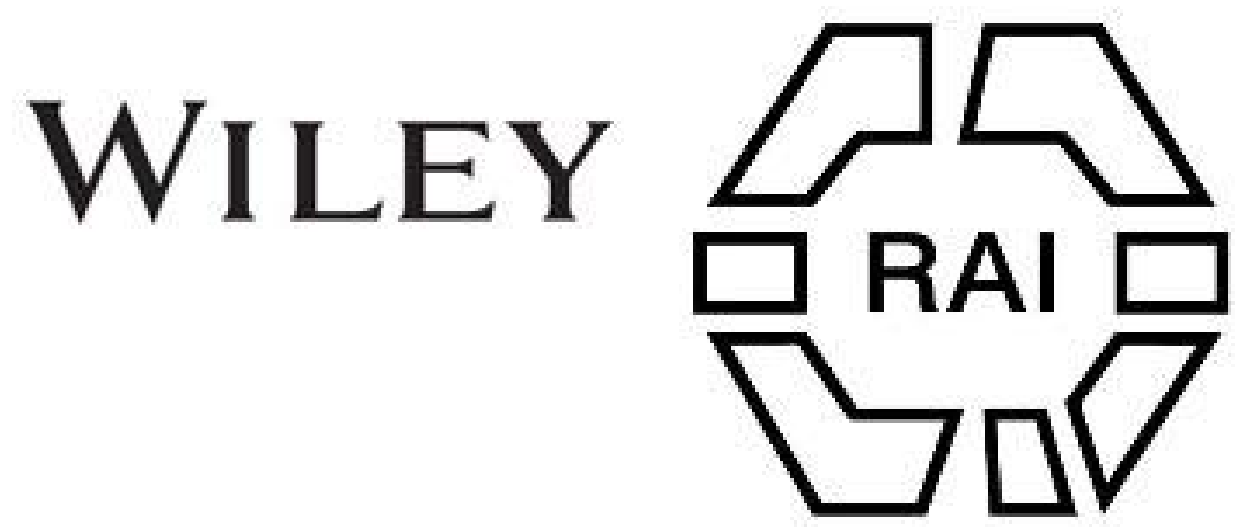

\title{
1. Note on Stone Pestles from British New Guinea.
}

\section{Author(s): F. R. Barton}

Source: Man, Vol. 8 (1908), pp. 1-2

Published by: Royal Anthropological Institute of Great Britain and Ireland

Stable URL: http://www.jstor.org/stable/2839897

Accessed: 15-06-2016 18:17 UTC

Your use of the JSTOR archive indicates your acceptance of the Terms \& Conditions of Use, available at

http://about.jstor.org/terms

JSTOR is a not-for-profit service that helps scholars, researchers, and students discover, use, and build upon a wide range of content in a trusted digital archive. We use information technology and tools to increase productivity and facilitate new forms of scholarship. For more information about JSTOR, please contact support@jstor.org.

Wiley, Royal Anthropological Institute of Great Britain and Ireland are collaborating with JSTOR to digitize, preserve and extend access to Man 


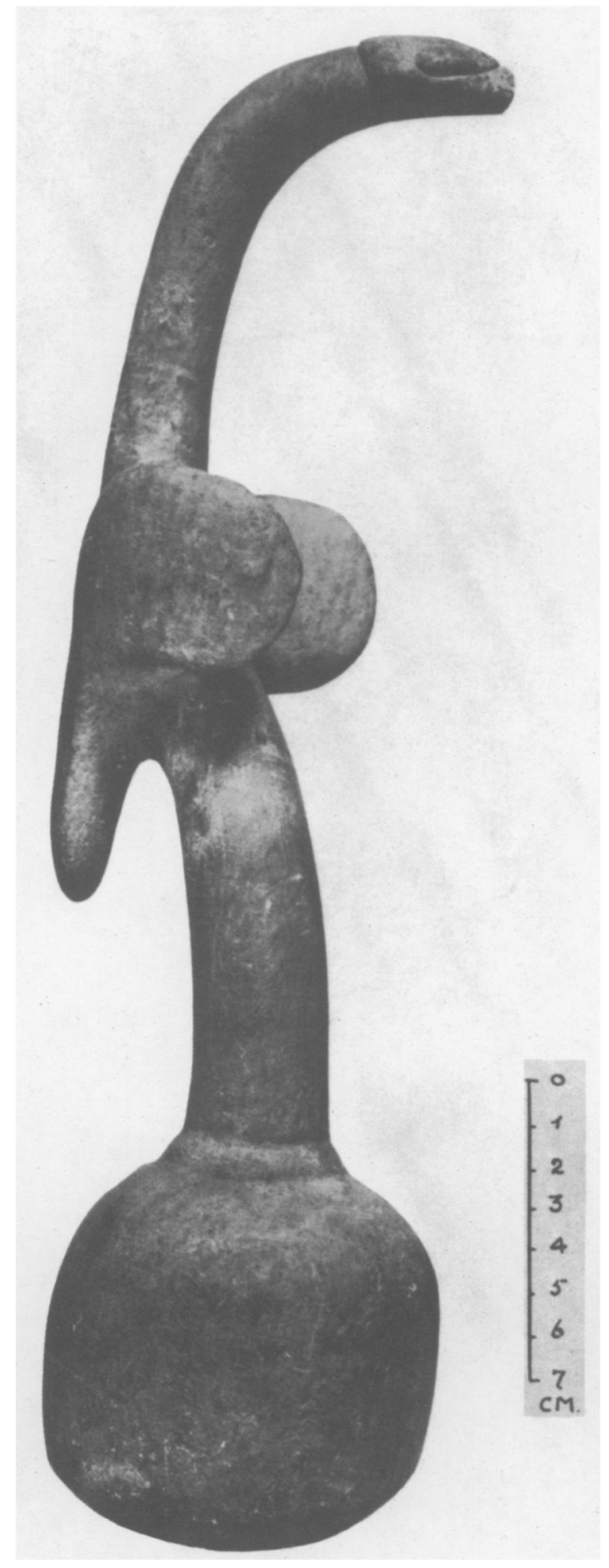

STONE PESTLE FROM BRITISH NEW GUINEA. All use subject to http://about.jstor.org/terms 


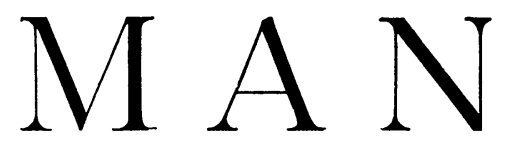

\section{A MONTHLY RECORD OF ANTHROPOLOGICAL SCIENCE.}

\section{PUBLISHED UNDER THE DIRECTION OF THE ROYAL ANTHROPOLOGICAL INSTITUTE OF GREAT BRITAIN AND IRELAND.}

N.B.-All communications printed in MAN are signed or initialled by their authors, and the Council of the Institute desires it to be understood that in giving publicity to them it accepts no responsibility for the opinions or statements expressed.

N.B.-M - $\mathrm{AN}$, 1908, consists of twelve monthly-published sheets, of sixteen pages each, printed in single column; containing "Original Articles" and substantial "Reviews" of recent publications; all numbered consecutively 1, 2, 3, onwards.

N.B. - Articles published in $\mathrm{M}_{\mathrm{AN}}$ should be quoted by the year and the reference-number of the article, not by the page-reference; e.g., the article which begins on $p$. 5 below should be quoted as MAN, 1908, 3.

\section{ORIGINAL ARTICLES.}

New Guinea: Stone Pestles. With Plate A.

Note on Stone Pestles from British New Guinea. By Captain F. R. Barton, C.M.G.

In a paper on "Prehistoric Objects in British New Guinea," by Seligmann and Joyce, which appeared in the volume of Anthropological Essays dedicated to Professor Tylor, is a description of a pestle and mortar found in the Yodda valley, and, on p. 329, the following sentence occurs :- "Several similar pes" tles, one of them a quite remarkable " piece of carving in stone, have been "found in this neighbourhood." On Plate A., figured herewith, is shown the "remarkable piece of carving in stone" to which reference is made in the passage just quoted. It is cut from solid greyishbuff stone which is close grained but not very hard; from the "business end" of the pestle, which resembles a compressed sphere, oval in vertical and horizontal section, with diameters of 95,86 , and $65 \mathrm{~mm}$., rises a column, circular in section and inclined slightly to one side, forming the handle, length $104 \mathrm{~mm}$. and diameter $31 \mathrm{~mm}$. ; at the top of this is carved the body of a bird, with tail depending and wings stretched outwards and forwards ; the neck of the bird is long $(135 \mathrm{~mm}$.) and curved, and terminates in a rather

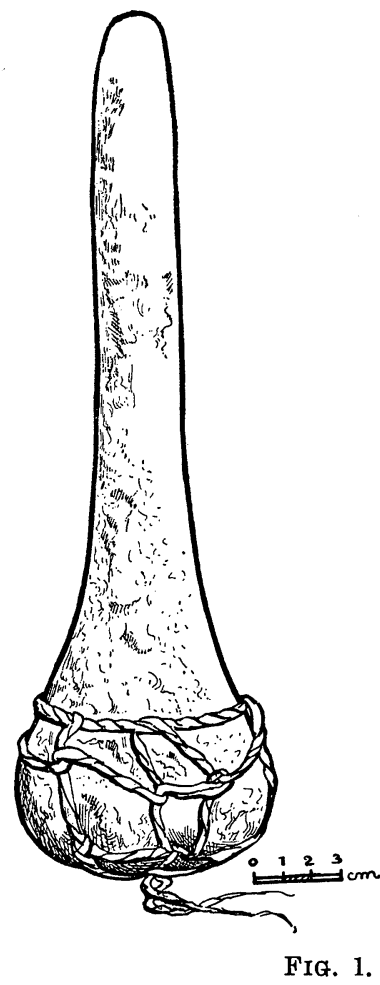

FIG. 1.

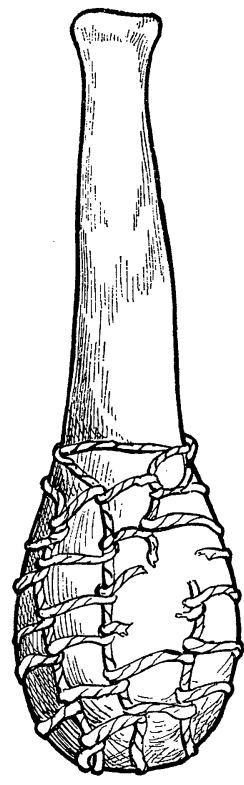

1 ] 
snake-like head, with eyes in relief ; the bill has been broken off immediately below the nostrils, which are represented by two small circular pits. The total length of the implement is $360 \mathrm{~mm}$.

Unfortunately I can give no details concerning it, save that it was found by a gold-miner, about 40 feet above the present bed of the Aikora (the northern branch of the Gira River) and under 10 feet of alluvial sand and clay. The grinding surface of the pestle is somewhat worn and polished, but, having regard to the peculiar elaboration of its shape and the softness of the stone from which it was cut, I am inclined to think that it was probably for ceremonial use.

Two other pestles, both of dark volcanic rock, are shown in Fig. 1. These were found at Cape Nelson in the possession of present-day natives, who, however, regarded them as charms, and had covered them with the customary network. I need hardly remark that pestles and mortars have not been found in use among any tribe in New Guinea. Both these pestles are circular in horizontal section ; one decreases rapidly to a long tapering handle, total length $316 \mathrm{~mm}$., the other lessens in diameter more gradually towards the handle, which is furnished at the end with a "stop-ridge," total length $255 \mathrm{~mm}$. The three pestles are now in the British Museum.

F. R. BARTON.

\section{Africa, West : Benin. Joyce. \\ Note on the Relation of the Bronze Heads to the Carved Tusks, Benin City. By T. A. Joyce, M.A.}

The carved ivory tusks and the human heads in cast bronze, which form some of the chefs d'ceuvre of Bini artisans, are too well known to ethnographers to need any introduction ; but the question of the inter-relation of the two has from the first proved a stumbling block to students on the Continent, and it is in the hope of settling the matter definitely once and for all that I venture to publish certain information which has recently come into my possession through the kindness of my friend Mr. R. E. Dennett, well known as an authority on West African ethnology and folklore.

I understand that the position is as follows: The authorities in Germany do not deny that the carved tusks were occasionally supported on bronze heads of some description ; but they refuse to accept the conclusion formed by Messrs. Read and Dalton that these heads are to be identified with the pattern having a circular aperture in the centre of the crown, figured by them in Antiquities from Benin in the British Museum, Pl. ix, Figs. 5 and 6.

Professor von Luschan writes (Verhl. der Berl. Anthr. Gesellsch., 1898, 161): "Dass sie als Sockel für die geschnitzten Zähne gedient haben . . . ist aber " doch technisch höchst unwahrscheinlich," and gives as his reason that the aperture in the crown is not sufficiently large to admit the end of a tusk. This objection, however, is not very serious; the aperture is structural, and has no necessary connection with the tusk, and the latter stood on the head, and not in the hole. This, I believe, is the only argument which has been brought against the theory that this particular type of head formed a pedestal for a tusk, and it is not very formidable.

As to the arguments in favour of the theory, Nyendael, in 1702, states clearly (Pinkerton's Voyages, xvi, 535) that bronze heads of some kind or other were used in this way. In the King's court "behind a white carpet we were also shown " eleven men's heads cast in copper, by much as good an artist as the former $\left[\begin{array}{ll}2 & ]\end{array}\right.$ 